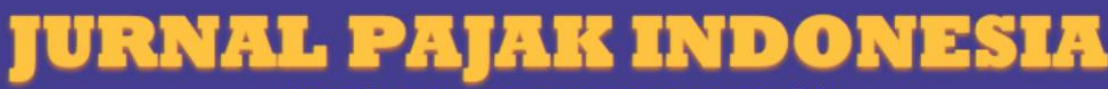

( Indonesian Tax Journal)

www.jurnal.stan.ac.id/index.php/JPI

\section{DINAMIKA PERUBAHAN EKONOMI MAKRO \\ DAN DAMPAKNYA TERHADAP PERTUMBUHAN \\ PENERIMAAN PAJAK PENGHASILAN NON MIGAS}

\author{
Mas'udin \\ Politeknik Keuangan Negara STAN \\ masudin@pknstan.ac.id
}

INFORMASI ARTIKEL
Diterima Pertama
20-11-2017
Dinyatakan Diterima
26-11-2017
KATA KUNCl:
Pajak Penghasilan Migas, Ekonomi Makro,
Vector Auto Regressive.

KLASIFIKASI JEL:

H200; E600

\begin{abstract}
ABSTRAK
This study examines an impact of macroeconomic on tax revenues, especially non oil and gas income tax. The time period of research is from 1970 to 2016. The research was conducted to obtain an empirical evidence of factors influencing the growth of non oil tax revenues in Indonesia. The model was analyzed using Vector Auto Regressive. The Granger causality test shows that there is one way relationship between economic growth and inflation rate with non oil and gas income tax. Changes in exchange rate indirectly have a significant effect on non oil and gas income tax. The Impuls Response Function shows that the growth of non oil and gas income tax achieves the fastest stability in the case of shock inflation rate compared to shocks over other variables.
\end{abstract}

Studi ini mengkaji dampak ekonomi makro terhadap penerimaan perpajakan, khususnya Pajak Penghasilan non migas. Rentang periode kajian dari 1970 s.d 2016. Studi dilakukan guna mendapatkan bukti empiris faktor-faktor yang mempengaruhi pertumbuhan penerimaan PPh non migas di Indonesia. Model dianalisis dengan menggunakan Vector Auto Regressive. Hasil uji kausalitas menunjukkan terdapat hubungan satu arah antara pertumbuhan ekonomi dan tingkat inflasi dengan PPh non migas. Perubahan nilai tukar rupiah secara tidak langsung mempunyai pengaruh yang signifikan terhadap PPh non migas. Hasil analisis Impuls Respon Function menyatakan bahwa Pertumbuhan PPh non migas mencapai kestabilan tercepat pada saat adanya guncangan inflasi dibandingkan dengan guncangan atas variabel lainnya. 


\section{PENDAHULUAN}

\subsection{Latar Belakang}

Dalam rentang waktu 46 tahun terakhir yaitu tahun 1970 hingga 2016, komposisi struktur pendapatan negara mengalami beberapa perubahan. Struktur pendapatan negara pada tahun 1970 hingga 1972, didominasi oleh penerimaan perpajakan. Namun, kemudian terjadi pergeseran struktur pendapatan negara dimana proporsi PNBP lebih besar jika dibandingkan dengan penerimaan perpajakan pada periode 1974 hingga 1987. Selanjutnya, penerimaan perpajakan kembali memberikan kontribusi yang signifikan sejak 1988 hingga 2016. Penerimaan perpajakan mencakup $82,6 \%$ dari total pendapatan negara, PNBP mencakup 16,8 \%, dan penerimaan hibah sebesar 0,6\% pada tahun 2016.

Penerimaan perpajakan terdiri dari penerimaan pajak dalam negeri dan pajak perdagangan internasional. Penerimaan pajak dalam negeri meliputi penerimaan Pajak Penghasilan (PPh), Pajak pertambahan nilai (PPn), pajak bumi dan bangunan (PBB), bea perolehan hak atas tanah dan bangunan (BPHTB), cukai dan pajak lainnya. Sedangkan penerimaan pajak perdagangan internasional terdiri dari penerimaan bea masuk dan bea keluar. Perkembangan kontribusi penerimaan jenis Pajak terhadap total penerimaan perpajakan 1970 hingga 2016 disajikan pada Tabel 1.

Tabel 1

Kontribusi Penerimaan Jenis Pajak Terhadap Total Penerimaan Perpajakan

\begin{tabular}{|l|r|r|r|r|r|r|}
\hline \multicolumn{1}{|c|}{ Jenis Pajak } & \multicolumn{1}{|c|}{1970} & \multicolumn{1}{c|}{1980} & \multicolumn{1}{c|}{1990} & \multicolumn{1}{c|}{2000} & \multicolumn{1}{c|}{2010} & \multicolumn{1}{c|}{2016} \\
\hline PPh & 22.3 & 38.2 & 37.5 & 49.2 & 49.4 & 51.1 \\
PPn & 18.0 & 15.9 & 36.9 & 30.4 & 31.9 & 32.1 \\
PBB & 0.0 & 3.3 & 3.6 & 3.0 & 4.0 & 1.5 \\
BPHTB & 0.0 & 0.0 & 0.0 & 0.8 & 1.1 & - \\
Cukai & 5.8 & 14.9 & 8.2 & 9.7 & 9.2 & 11.2 \\
Pajak Lainnya & 1.9 & 0.9 & 1.0 & 0.7 & 0.6 & 1.3 \\
Pajak Perdagangan Internasional & 51.9 & 26.8 & 12.9 & 6.1 & 4.0 & 2.8 \\
\hline \multicolumn{1}{|c|}{ Total } & 100.00 & 100.00 & 100.00 & 100.00 & 100.00 & 100.00 \\
\hline
\end{tabular}

Sumber : Kementerian Keuangan, data diolah.

Kontribusi penerimaan PPh terhadap total penerimaan perpajakan pada tahun 1970 mencapai $22,3 \%$. Penerimaan PPh tersebut menunjukkan trend peningkatan selama 46 tahun terakhir. Pada tahun 2016, penerimaan PPh mencapai 51,1 \% dari total penerimaan perpajakan. Penerimaan PPh tersebut mulai mendominasi pendapatan negara sejak tahun 1975.

Penerimaan PPh terdiri dari penerimaan Pajak Penghasilan migas dan Pajak Penghasilan non migas. Dalam rentang periode 1970 hingga 1998 penerimaan PPh migas dicatat sebagai bagian dari penerimaan PNBP sumber daya alam migas. Mulai tahun 1999, Pemerintah melakukan koreksi dan mencatat penerimaan Pajak Penghasilan migas sebagai bagian dari PPh dalam postur APBN. Penerimaan PPh migas meliputi PPh minyak bumi, gas alam, dan PPh migas lainnya. Sedangkan PPh non migas meliputi PPh Pasal 21, PPh Pasal 22, PPh Pasal 22 impor, PPh Pasal 23, PPh Pasal 25/29 orang pribadi, PPh Pasal 25/29 badan, PPh Pasal 26, PPh final dan fiskal
LN, pendapatan PPh ditanggung oleh Pemerintah, dan PPh non migas lainnya.

Realisasi PPh non migas pada tahun 1970 mencapai $22,3 \%$ dari total penerimaan perpajakan meningkat menjadi $32,4 \%$ pada tahun 1975 , dan meningkat kembali secara signifikan menjadi $47,4 \%$ pada tahun 2016. Pertumbuhan penerimaan PPh non migas tersebut terkait dengan pelaksanaan serangkaian kebijakan Pemerintah dibidang perpajakan antara lain melalui intensifikasi dan ekstensifikasi pajak.

Selain itu, dinamika ekonomi baik domestik maupun global berdampak pada realisasi APBN. Indikator ekonomi makro yang digunakan sebagai asumsi dasar dalam penyusunan APBN meliputi pertumbuhan ekonomi, tingkat inflasi, nilai tukar rupiah terhadap dolar Amerika Serikat, suku bunga Surat Perbendaharaan Negara (SPN) tiga bulan, harga minyak mentah Indonesia (Indonesia Crude Price/ICP), lifting minyak, dan lifting gas (Pemerintah Republik Indonesia, 2017). Transmisi dari perubahan asumsi dasar ekonomi makro tersebut terhadap pendapatan negara dijelaskan sebagai berikut.

Pertumbuhan ekonomi mempengaruhi besaran APBN, baik pada sisi pendapatan maupun belanja negara. Pada sisi pendapatan negara, perubahan pertumbuhan ekonomi antara lain memengaruhi penerimaan perpajakan, terutama PPh nonmigas, PPN, PBB, cukai, pajak lainnya, dan bea masuk. Laju inflasi mempengaruhi APBN melalui produk domestik bruto (PDB) nominal. Perubahan PDB nominal berdampak pada perubahan penerimaan perpajakan terutama PPh nonmigas, PPN, PBB, dan pajak lainnya. Fluktuasi nilai tukar rupiah terhadap dolar Amerika Serikat memiliki dampak pada semua sisi APBN, baik pendapatan negara, belanja negara, maupun pembiayaan anggaran. Perubahan tersebut terjadi terutama pada anggaran yang menggunakan mata uang dolar Amerika Serikat sebagai komponen penghitungan. Pada sisi pendapatan negara, fluktuasi nilai tukar rupiah antara lain akan memengaruhi penerimaan yang terkait dengan aktivitas perdagangan internasional seperti PPh pasal 22 impor, PPN dan PPnBM impor, bea masuk, dan bea keluar. Selain itu, perubahan nilai tukar rupiah juga akan berdampak pada penerimaan PPh migas dan PNBP SDA migas. Harga minyak mentah Indonesia memengaruhi besaran APBN terutama pada anggaran yang menggunakan harga minyak mentah sebagai komponen penghitungan. Pada sisi pendapatan negara, perubahan harga minyak mentah akan berdampak terhadap penerimaan PPh migas dan PNBP SDA migas (Pemerintah Republik Indonesia, 2017).

Rata-rata pertumbuhan ekonomi Indonesia dalam periode 1970 s.d 2016 sebesar 5,6 \%. Pertumbuhan ekonomi tertinggi dicapai pada tahun 1990 sebesar 9,9 \%. Dalam rentang periode 1970 s.d 1997 Indonesia mengalami pertumbuhan ekonomi yang signifikan rata-rata sebesar 6,6\%. Namun, pada tahun 1998 laju pertumbuhan ekonomi Indonesia mencapai titik terendah sebesar minus $13,1 \%$ akibat dari krisis moneter. Pascakrisis moneter, pertumbuhan ekonomi Indonesia mengalami perbaikan. Dalam rentang periode 1999 s.d 2016, Pertumbuhan ekonomi Indonesia berada pada kisaran rata-rata 5,1 \%. 
Rata-rata tingkat inflasi Indonesia dalam periode 1970 s.d 2016 sebesar 11,3\%. Dalam rentang periode 1972 s.d 1980 tingkat inflasi Indonesia juga relatif tinggi mencapai $19,2 \%$. Namun, kemudian dalam periode setelahnya pada 1981 s.d 1997 menunjukkan penurunan mencapai rata-rata $8,2 \%$. Tingkat inflasi tertinggi dicapai pada saat terjadi krisis moneter tahun 1998 sebesar 77,6 \%. Setelah puncak krisis pada tahun 1998, laju Inflasi Indonesia berada pada kisaran ratarata $7,1 \%$.

Harga minyak Indonesia (ICP) dalam periode 1970 s.d 2016 fluktuatif. Harga minyak Indonesia (ICP) dalam periode 1970 s.d 2016 mengalami kenaikan ratarata $11,2 \%$. Kenaikan harga minyak Indonesia tertinggi dicapai pada tahun 1974 sebesar 158,9 \% dan tahun 1999 sebesar 131,2 \%. Sedangkan penurunan harga minyak terbesar pada tahun 2015 sebesar 49,0 \% dan pada tahun 1986 sebesar 41,0 \%. Pada saat krisis ekonomi, harga minyak juga mengalami penurunan yang signifikan yaitu 27,9 \% pada tahun 1997 dan 38,4 \% pada tahun 1998.

Nilai tukar rupiah terhadap USD dalam periode 1970 s.d 2016 mengalami pelemahan rata-rata mencapai 10,0 \%. Rupiah mengalami pelemahan tertinggi pada saat krisis moneter 1997 dan 1998. Dalam tahun 1997 rupiah mengalami pelemahan tertinggi mencapai 95,1\% dan pada tahun 1998 rupiah mengalami pelemahan mencapai $72,6 \%$.

Studi-studi untuk mendapatkan bukti empiris pengaruh pertumbuhan ekonomi terhadap penerimaan pajak sudah banyak dilakukan. Studi oleh Rahmanta (2009), Edeme (2016), dan Sitinjak (2016) menemukan bahwa semakin tinggi nilai Produk Domestik Bruto maka pendapatan per kapita masyarakat juga meningkat sehingga penerimaan Pajak Penghasilan dan pajak lainnya akan meningkat. Sementara itu, studi yang mengkaitkan pola hubungan antara tingkat inflasi dengan penerimaan pajak menemukan hasil yang berbeda. Pertama, Inflasi tidak mempunyai pengaruh terhadap penerimaan perpajakan ditemukan oleh Richard (2013), Pratama (2016), Kurniawan (2007), dan Prawironegoro (2011). Kedua, tingkat inflasi berpengaruh negatif terhadap rata-rata penerimaan pajak ditemukan oleh Crane (1986), Saepudin (2008), Arianto (2014). Ketiga Inflasi berpengaruh terhadap penerimaan PPN secara positif dan signifikan ditemukan oleh Renata (2016). Sementara itu, studi yang mengkaitkan nilai tukar dengan penerimaan perpajakan juga menemukan hasil yang berbeda. Renata (2016) menemukan bahwa nilai tukar berpengaruh terhadap penerimaan PPN secara negatif dan signifikan. Sebaliknya, penelitian yang dilakukan oleh Karlina (2016) menemukan bahwa nilai tukar berpengaruh secara positif dan signifikan atas penerimaan pajak di KPP Madya Bandung. Selanjutnya, Lisnawati (2016) menemukan bahwa turunnya harga minyak dunia memberikan dampak positif maupun dampak negatif bagi perekonomian Indonesia. Dampak negatif di antaranya penurunan kinerja ekspor migas dan penurunan realisasi dalam APBN terkait Pajak Penghasilan minyak dan gas. Dampak positif di antaranya menurunnya biaya energi dan transportasi sehingga dapat meningkatkan ekspor menjadi lebih kompetitif.

Riset-riset guna mendapatkan bukti empiris pengaruh variabel ekonomi makro terhadap penerimaan pajak memberikan hasil yang berbeda. Untuk itu studi ini akan mendalami lebih lanjut pengaruh indikator ekonomi makro terhadap penerimaan perpajakan. Rentang periode kajian selama 46 tahun terakhir yaitu dari 1970 s.d 2016. Lingkup kajian dibatasi pada penerimaan PPh non migas mengingat PPh non migas mempunyai peranan besar sebagai salah satu kontributor utama pendapatan negara Republik Indonesia sejak tahun 1975 hingga saat ini. Sedangkan indikator ekonomi makro yang dikaji meliputi pertumbuhan ekonomi, tingkat inflasi, nilai tukar rupiah terhadap USD, dan harga minyak mentah Indonesia (ICP). Studi dilakukan guna mendapatkan bukti empiris faktor-faktor yang mempengaruhi pertumbuhan penerimaan PPh non migas di Indonesia.

\section{LANDASAN TEORI}

\subsection{Pajak Penghasilan Non Migas}

Pajak Penghasilan terdiri dari Pajak Penghasilan Migas dan Pajak Penghasilan Nonmigas. Pajak Penghasilan Migas terdiri dari PPh minyak bumi, PPh gas alam, dan PPh migas lainnya. Sementara itu, PPh non migas terdiri dari pendapatan PPh Pasal 21, PPh Pasal 22, PPh Pasal 22 Impor, PPh Pasal 23, PPh Pasal 25/29 Orang Pribadi, PPh Pasal 25/29 Badan, PPh Pasal 26, PPh Final, PPh Fiskal Luar Negeri, Pendapatan PPh Ditanggung Pemerintah dan PPh Non Migas Lainnya.

Pajak Penghasilan (PPh) Pasal 21 adalah pajak atas penghasilan berupa gaji, upah, honorarium, tunjangan, dan pembayaran lain dengan nama dan dalam bentuk apapun sehubungan dengan pekerjaan ataupun jabatan, jasa, dan kegiatan yang dilakukan oleh orang pribadi subjek pajak dalam negeri. Pajak Penghasilan (PPh) Pasal 22 merupakan PPh yang dipungut oleh (1) Bendahara Pemerintah Pusat/Daerah, instansi atau lembaga pemerintah dan lembagalembaga negara lainnya, berkenaan dengan pembayaran atas penyerahan barang; (2) Badan-badan tertentu, baik badan pemerintah maupun swasta berkenaan dengan kegiatan di bidang impor atau kegiatan usaha di bidang lain; dan (3) Wajib Pajak Badan yang melakukan penjualan barang yang tergolong sangat mewah. Sementara itu, Pajak Penghasilan (PPh) Pasal 23 merupakan pajak yang dipotong atas penghasilan yang berasal dari modal, penyerahan jasa, atau hadiah dan penghargaan, selain yang telah dipotong PPh Pasal 21.

Pajak Penghasilan Pasal 25 (PPh Pasal 25) merupakan pembayaran Pajak Penghasilan secara angsuran. Tujuannya adalah untuk meringankan beban Wajib Pajak, mengingat pajak yang terutang harus dilunasi dalam waktu satu tahun. Wajib Pajak (WP), baik berupa Orang Pribadi atau pun Badan yang melakukan suatu kegiatan usaha dikenai Pajak Penghasilan (PPh) Pasal 25 berupa angsuran PPh tiap bulannya. Pajak Penghasilan (PPh) Pasal 26 merupakan PPh yang dikenakan/dipotong atas penghasilan yang bersumber dari Indonesia yang diterima atau diperoleh Wajib Pajak 
(WP) luar negeri selain bentuk usaha tetap (BUT) di Indonesia. Bentuk usaha tetap merupakan subjek pajak yang perlakuan perpajakannya dipersamakan dengan subjek pajak badan. Negara domisili dari Wajib Pajak luar negeri selain yang menjalankan usaha atau melakukan kegiatan usaha melalui bentuk usaha tetap di Indonesia, adalah Negara tempat tinggal atau tempat kedudukan Wajib Pajak luar negeri yang sebenarnya menerima manfaat dari penghasilan tersebut (beneficial owner).

Pajak Penghasilan Pasal 29 (PPh 29) merupakan PPh Kurang Bayar (KB) yang tercantum dalam SPT Tahunan PPh, yaitu sisa dari PPh yang terutang dalam tahun pajak yang bersangkutan dikurangi dengan kredit PPh (PPh Pasal 21, 22, 23, dan 24) dan PPh Pasal 25. Wajib Pajak (WP) wajib memiliki kewajiban melunasi kekurangan pembayaran pajak yang terutang. Pajak Penghasilan (PPh) Final merupakan pajak yang dikenakan atas penghasilan-penghasilan tertentu yang dikenai PPh dengan tarif tertentu (final) baik melalui pemotongan oleh pihak lain atau dengan menyetor sendiri. Pemerintah mengeluarkan kebijakan PPh final atas penghasilan tertentu dengan pertimbangan perlu adanya dorongan dalam rangka perkembangan investasi dan tabungan masyarakat, kesederhanaan dalam pemungutan pajak, berkurangnya beban administrasi baik bagi Wajib Pajak maupun Direktorat Jenderal Pajak, pemerataan dalam pengenaan pajaknya, dan memperhatikan perkembangan ekonomi dan moneter. PPh Fiskal Luar Negeri merupakan Pajak Penghasilan yang wajib dibayar oleh Wajib Pajak orang pribadi dalam negeri yang akan bertolak ke luar negeri sesuai dengan peraturan perundang-undangan perpajakan. Selanjutnya, Pajak Penghasilan ditanggung Pemerintah adalah pajak yang terhutang dari Wajib Pajak namun pembayaran pajaknya dibayar oleh pemerintah, sehingga wajib pajak tidak perlu membayar pajak.

\subsection{Faktor Penentu Penerimaan Pajak Penghasilan Non Migas}

Sebagaimana disampaikan oleh Pemerintah dalam Nota Keuangan dan Anggaran Pendapatan dan Belanja Negara setiap tahun anggaran, penerimaan perpajakan ditentukan oleh kebijakan Pemerintah di bidang perpajakan dan perkembangan ekonomi makro. Yang termasuk dalam ranah kebijakan Pemerintah antara lain tarif pajak, kebijakan dalam mendorong kepatuhan wajib pajak (tax compliance), sistem perpajakan (tax system), aturan perpajakan (tax regulation), kelembagaan perpajakan (tax institution), dasar pengenaan pajak atau obyek pajak (tax base), kebijakan perpajakan dalam meningkatkan daya beli masyarakat, iklim investasi, dan daya saing industri nasional, untuk pengendalaian konsumsi barang tertentu dan negative externality. Sedangkan indikator ekonomi makro yang digunakan sebagai asumsi dasar dalam penyusunan APBN meliputi pertumbuhan ekonomi, tingkat inflasi, nilai tukar rupiah terhadap dolar Amerika Serikat, suku bunga Surat Perbendaharaan Negara (SPN) tiga bulan, harga minyak mentah Indonesia (Indonesia Crude
Price/ICP), lifting minyak, dan lifting gas (Pemerintah Republik Indonesia, 2017).

Secara matematis jumlah penerimaan pajak dapat dirumuskan sebagai berikut:

$\mathrm{T}=\mathrm{tB}$

Berdasarkan persamaan di atas, jumlah penerimaan pajak (Tax Revenue/T) dipengaruhi oleh tarif pajak (t) dan basis pajak (Tax Base/B). Tarif pajak dan basis dapat berubah jika Pemerintah menetapkan kebijakan yang berbeda dengan kebijakan yang ditempuh sebelumnya. Kebijakan tersebut dapat berupa perubahan tarif pajak, perluasan atau pengurangan basis pajak dengan menetapkan obyek pajak baru atau membebaskan obyek pajak dari dasar pengenaan pajak (basis pajak). Dalam hal kebijakan Pemerintah tidak berubah, maka perubahan penerimaan pajak disebabkan oleh naik atau turunnya nilai basis pajak.

Studi yang dilakukan Badan Kebijakan Fiskal (2017) menemukan adanya hubungan/korelasi positif antara basis pajak dengan besarnya penerimaan pajak. Keterkaitan antara basis pajak dengan asumsi dasar ekonomi makro disampaikan sebagai berikut.

\subsection{Keterkaitan Pertumbuhan Ekonomi dengan Penerimaan Pajak Penghasilan}

Pertumbuhan ekonomi merupakan perkembangan aktivitas perekonomian yang mengakibatkan jumlah agregat barang dan jasa yang dihasilkan masyarakat meningkat (Sukirno, 2011). Suatu negara dapat dikatakan mengalami pertumbuhan ekonomi yang positif apabila kuantitas barang dan jasa yang dihasilkan negara tersebut mengalami kenaikan. Oleh karena itu untuk mengukur pertumbuhan ekonomi atau pertumbuhan output dilakukan dengan menggunakan perubahan nilai yang tercermin dalam Produk Domestik Bruto. Dasar pengenaan Pajak Penghasilan adalah penghasilan baik perorangan maupun badan hukum. Faktor-faktor yang dapat mempengaruhi besar kecilnya penghasilan perorangan maupun badan hukum akan mempengaruhi penerimaan Pajak Penghasilan. Pada level makro, penghasilan total dari seluruh penduduk dalam sebuah negara adalah Produk Domestik Bruto (PDB). Semakin besar kenaikan PDB dibandingkan dengan tahun sebelumnya maka pertumbuhan ekonomi akan semakin meningkat.

Jika terjadi kenaikan pertumbuhan ekonomi, maka hal tersebut akan memberikan dampak bertambahnya basis pajak. Karena saat ekonomi mengalami pertumbuhan yang biasanya ditandai dengan meningkatnya konsumsi masyarakat, menyebabkan permintaan akan barang dan jasa mengalami kenaikan. Naiknya permintaan akan mendorong perusahaan menambah penawaran dengan meningkatkan produksi. Peningkatan produksi akan meningkatkan pendapatan baik bagi perusahaan maupun masyarakat. Hal ini akan meningkatkan basis Pajak Penghasilan (Badan Kebijakan Fiskal, 2017). Basis Pajak Penghasilan yang meningkat akan meningkatkan penerimaan pajak. Studi yang dilakukan Rahmanta 
(2009), Edeme (2016), dan Sitinjak (2016) memperkuat hal ini. Menurut Rahmanta (2009) semakin tinggi nilai Produk Domestik Bruto maka pendapatan per kapita masyarakat juga meningkat sehingga penerimaan Pajak Penghasilan dan pajak lainnya akan meningkat. Studi yang dilakukan Edeme (2016) menemukan bahwa pertumbuhan PDB diikuti oleh kenaikan penerimaan pajak. Sedangkan Sitinjak (2016) menemukan bahwa PDB berpengaruh positif terhadap penerimaan pajak pemerintah pusat, artinya semakin tinggi PDB maka penerimaan pajak pemerintah pusat akan semakin tinggi.

\subsection{Keterkaitan Inflasi dengan Penerimaan Pajak Penghasilan}

Inflasi merupakan kecenderungan naiknya secara terus menerus harga barang dan jasa yang mengakibatkan penurunan daya beli dari nilai uang (BPS, 2016). Inflasi mempengaruhi seluruh variabel makro ekonomi, seperti pertumbuhan ekonomi, ekspor impor, tingkat bunga, investasi, distribusi pendapatan, dan penerimaan pajak (Nersiwad, 2002). Kebijakan yang dilakukan untuk mengendalikan tingkat inflasi dapat berupa kebijakan fiskal dan kebijakan moneter (Sukirno, 2004). Pengendalian tingkat inflasi melalui perangkat kebijakan fiskal dilakukan dengan menambah pajak dan mengurangi pengeluaran Pemerintah. Sedangkan pengendalian inflasi melalui kebijakan moneter dilakukan dengan menaikkan tingkat suku bunga dan membatasi kredit.

Saat terjadi inflasi, maka harga barang-barang secara umum naik. Kenaikan harga akan memicu penurunan terhadap permintaan barang, yang akan diikuti oleh perusahaan dengan mengurangi jumlah penawaran barang dengan mengurangi jumlah produksinya. Sehingga akan menyebabkan jumlah pendapatan perusahaan akan mengalami penurunan, demikian juga dengan pendapatan masyarakat karena terjadinya penurunan penggunaan faktor produksi tenaga kerja. Pada akhirnya hal ini akan menyebabkan penurunan pendapatan baik perusahaan maupun bagi masyarakat, sehingga basis Pajak Penghasilan akan menjadi berkurang (Badan Kebijakan Fiskal, 2017).

Studi tentang hubungan antara tingkat inflas dengan penerimaan pajak sudah banyak dilakukan. Hasil studi menemukan adanya hasil yang berbeda antara satu dengan lainnya. Richard (2013) melakukan penelitian hubungan antara variabel inflasi, pertumbuhan ekonomi, struktur ekonomi, serta tariff pajak terhadap pendapatan pajak di negara-negara ASEAN. Hasil penelitiannya menunjukkan bahwa inflasi dan pertumbuhan ekonomi tidak mempunyai korelasi terhadap pendapatan pajak. Namun struktur ekonomi dan tarif pajak memiliki korelasi positif dan signifikan terhadap pendapatan pajak. Hasil studi yang berbeda disampaikan oleh Kurniawan (2007), Saepudin (2008), Crane (1986), dan Pratama (2016). Sedangkan hasil penelitian Crane dan Nourzad (1986) menemukan bahwa tingkat inflasi berpengaruh negatif terhadap rata-rata penerimaan pajak. Hasil penelitian Pratama et, al (2016) menemukan bahwa variabel pemeriksaan pajak dan jumlah wajib pajak berpengaruh signifikan terhadap penerimaan Pajak Penghasilan, sedangkan variabel inflasi tidak berpengaruh signifikan terhadap penerimaan Pajak Penghasilan. Kurniawan (2007) menemukan bahwa pertumbuhan ekonomi berpengaruh positif dan signifikan terhadap realisasi penerimaan PPN barang dan jasa dan PPnBM di Indonesia, sedangkan tingkat inflasi tidak berpengaruh nyata terhadap besarnya penerimaan PPN barang dan jasa dan PPnBM di Indonesia. Sementara itu Saepudin (2008), menemukan bahwa secara serempak jumlah pengusaha kena pajak, inflasi periode sebelumnya dan pertumbuhan ekonomi mempunyai pengaruh yang signifikan terhadap pajak pertambahan nilai. Secara parsial jumlah pengusaha kena pajak dan pertumbuhan ekonomi mempunyai pengaruh positif dan signifikan sedangkan inflasi periode sebelumnya mempunyai pengaruh negatif dan signifikan terhadap pajak pertambahan nilai di Sumatera Utara.

Di tingkatan Pemerintah Daerah, riset-riset yang mengkaitkan makro ekonomi dengan penerimaan Pajak Daerah juga telah banyak dilakukan. Hasil penelitian Arianto, et.al (2014) menemukan bahwa jumlah penduduk berpengaruh positif terhadap penerimaan pajak daerah, inflasi berpengaruh negatif terhadap penerimaan pajak daerah dan PDRB berpengaruh secara positif terhadap penerimaan pajak daerah di kota Surabaya. Prawironegoro (2011) menemukan bahwa jumlah wajib pajak, dan pertumbuhan ekonomi berpengaruh terhadap penerimaan pajak daerah. Namun demikian tingkat inflasi tidak berpengaruh secara signifikan. Hal tersebut mengindikasikan bahwa meskipun barang dan jasa naik, tidak berpengaruh akan kesadaran dan kepatuhan masyarakat untuk membayar pajak.

Berbagai studi tersebut menghasilkan pola hubungan antara tingkat inflasi dengan penerimaan pajak yang berbeda yang dapat dirangkum dalam dua rangkuman sebagai berikut : Pertama, Inflasi tidak mempunyai pengaruh terhadap penerimaan perpajakan ditemukan oleh Richard (2013), Pratama (2016), Kurniawan (2007), dan Prawironegoro (2011). Kedua, tingkat inflasi berpengaruh negatif terhadap rata-rata penerimaan pajak ditemukan oleh Crane (1986), Saepudin (2008), Arianto (2014).

\subsection{Keterkaitan Nilai Tukar dengan Penerimaan Pajak Penghasilan}

Nilai tukar merupakan harga mata uang suatu negara dinyatakan dalam mata uang negara lain. Nilai tukar (kurs) dibedakan menjadi dua yakni kurs nominal (nominal exchange rate) yaitu harga relatif dari mata uang suatu negara dengan negara lain, dan kurs riil (real exchange rate) yaitu kurs nominal yang disesuaikan dengan tingkat harga. Perubahan nilai tukar mata uang berdampak terhadap apresiasi dan depresiasi mata uang. Apresiasi merupakan kenaikan nilai tukar negara tertentu terhadap nilai mata uang negara lain. Sedangkan depresiasi mata uang merupakan penurunan nilai tukar mata uang negara tertentu terhadap nilai mata uang negara lain (Berlianta, 2005). Perubahan nilai tukar ini berpengaruh langsung terhadap perkembangan harga barang dan jasa di dalam negeri 
(Puspitaningrum dkk, 2014). Perubahan nilai tukar juga akan berdampak terhadap penerimaan Pajak Penghasilan terutama penghasilan atas orang/badan asing di Indonesia. Untuk Pajak Penghasilan atas orang/badan asing, dasar pajaknya ditentukan oleh nilai tukar Rupiah terhadap mata uang asing karena penghitungan pajak terutang atas Pajak Penghasilan orang/badan asing tersebut adalah dalam mata uang Rupiah. Selain itu, dasar pengenaan Pajak Penghasilan impor adalah nilai impornya. Setiap kenaikan impor yang masuk ke Indonesia akan meningkatkan juga penerimaan Pajak Penghasilan atas impor.

\subsection{Keterkaitan Harga Minyak Indonesia dengan Penerimaan Pajak Penghasilan \\ Kenaikan harga minyak Indonesia akan} berpengaruh terhadap perekonomian dalam negeri sebagai efek inflasi yang berasal dari impor. Karena efek tersebut, biaya total produksi menjadi tinggi sehingga berpotensi menekan kinerja usaha yang berbahan baku berbasis impor. Akibatnya kenaikan harga minyak Indonesia menyebabkan menurunnya produksi barang dan jasa, dengan diikuti daya beli yang rendah maka menyebabkan penerimaan PPh menurun. Sedangkan untuk penerimaan PPh migas dimana dasar pajaknya adalah nilai migas yang diproduksi, maka kenaikan produksi maupun harga migas itu akan menaikkan dasar pajaknya yang secara otomatis meningkatkan penerimaan pajaknya.

Menurut Wahyudi (2009) harga minyak merupakan faktor penting yang mempengaruhi fluktuasi siklus bisnis Indonesia. Dengan demikian dampaknya akan menurunkan produktifitas daerah penghasil (cost push). Untuk itu variabel harga minyak tersebut penting untuk dikendalikan.

\section{METODE PENELITIAN}

\subsection{Data dan Definisi Operasional Variabel}

Penelitian ini menggunakan data sekunder. Data PPh non migas, pertumbuhan ekonomi, tingkat inflasi, nilai tukar rupiah, dan harga minyak Indonesia diperoleh dari Kementerian Keuangan, Badan Pusat Statistik RI dan Bank Indonesia. Jenis data yang digunakan yaitu data time series selama 46 tahun terakhir (1970 s.d 2016).

Definisi dan pengukuran variabel sebagai berikut :

1. PPh_NM = Pajak Penghasilan Non Migas. Pertumbuhan PPh non migas pertahun diukur dalam satuan \%.

2. Growth $=$ Pertumbuhan ekonomi per tahun (dalam satuan \%).

3. Inflasi = tingkat inflasi per tahun (dalam satuan \%).

4. Kurs $=$ nilai tukar rupiah terhadap USD. Kenaikan/penurunan nilai tukar tupiah terhadap USD diukur pertahun dalam satuan $\%$.

5. $\quad \mathrm{ICP}=$ harga minyak mentah Indonesia (Indonesian Crude Oil). Kenaikan/penurunan ICP pertahun diukur dalam satuan $\%$.

\subsection{Spesifikasi Model}

Model dianalisis dengan menggunakan VAR non restriktif. Menurut Gujarati (2004) VAR non-restriktif mempunyai fitur-fitur khusus sebagai berikut: (a) VAR merupakan sebuah sistem simultan dimana semua variabel dianggap endogen, tetapi tidak seperti persamaan simultan, VAR bersifat a-teoritis karena tidak membutuhkan teori yang mapan; (b) Dalam sistem VAR, nilai sebuah variabel diekpresikan sebagai sebuah fungsi linier nilai-nilai variabel itu sendiri di waktu sebelumnya (lag), dan semua variabel lainnya dimasukkan ke dalam model; (c) Apabila setiap persamaan mengandung jumlah variabel lag yang sama, maka estimasi cukup dilakukan dengan OLS tanpa perlu merujuk pada metode estimasi tertentu.

Metode VAR nonrestriktif dipilih sebagai instrumen studi karena merupakan alat analisis atau metode statistik yang cukup baik dalam memproyeksikan sistem variabel-variabel runtut waktu maupun untuk menganalisis dampak dinamis dari faktor shock yang terdapat dalam sistem variabel tersebut.

\subsection{Teknik Analisis Data}

Secara garis besar, disain VAR dalam studi ini mencakup tahapan-tahapan berikut: (1) Melakukan uji stasioneritas data melalui uji akar unit (unit root test). (2) Menentukan ordo VAR atau menentukan panjang kelambanan (lag). (3) Menentukan dan melakukan estimasi model VAR berdasarkan panjang lag yang telah ditentukan sebelumnya. (4) Melakukan analisis ekonometrika melalui impulse response function (IRF) dan variance decomposition (VDC).

\section{HASIL PENELITIAN}

\subsection{Uji Akar Unit (Unit Root Test)}

Model VAR hanya boleh dilakukan apabila seluruh data bersifat stasioner. Jika ada data yang tidak stasioner di level atau dengan kata lain memiliki akar unit (unit root), maka harus dilakukan penarikan diferensial sampai data stasioner pada tingkat first difference atau second difference. Uji akar unit dengan menggunakan ADF test terhadap masing-masing variabel ditujukan untuk menelaah kestasioneran data sekaligus menguji derajat integrasi. Jika pada tingkat level, data belum stasioner maka akan dilakukan first differencing. Data yang stasioner akan mempunyai nilai ADF statistik yang lebih kecil dari nilai kritisnya.

Hasil uji akar unit yang disajikan pada Lampiran 1 menunjukkan bahwa nilai probability ADF - Fisher Chisquare dan ADF - Choi Z-stat sebesar 0,0000 yang berarti lebih rendah dari derajat kepercayaan $5 \%$. Hasil tersebut menunjukkan bahwa semua variabel yang akan diolah memiliki stasioneritas di tingkat level, sehingga memungkinkan untuk melakukan pengolahan data menggunakan metode VAR. Nilai absolut akar dari uji stabilitas VAR pada penelitian ini memiliki modulus yang lebih kecil daripada satu. Artinya, model VAR yang digunakan sudah bersifat stabil.

\subsection{Penentuan lag optimal}

Apabila data yang didapat telah stasioner, maka langkah selanjutnya adalah menentukan lag optimum. Untuk memilih lag yang optimal digunakan kriteria informasi seperti Likehood Ratio (LR), Final 
Prediction Error (FPE), Akaike Information Criterion (AIC), Schwarz Information Criterion (SC), dan HannanQuin Criterion (HQ).

Berdasarkan kriteria LR, dan SC kandidat lag yang disarankan adalah lag 1 . Sementara itu, berdasarkan FPE, AIC, dan $\mathrm{HQ}$ kandidat lag yang disarankan adalah lag 6. Untuk memilih lag yang optimal, dilakukan dengan mengestimasi sistem VARnya baik pada lag 1 maupun lag 6 dan memilih sistem VAR dengan nilai adjusted $R$ squared yang tertinggi Juanda (2012). Lag 1 menghasilkan adjusted $R$ squared sebesar 55,2 \% sedangkan lag 6 menghasilkan adjusted $R$ squared sebesar 78,2\%. Dengan demikian lag optimalnya adalah lag 6. Hasil VAR Lag Order Selection Criteria disampaikan pada Lampiran 2.

\subsection{Identifikasi dan Estimasi Model VAR}

Dengan panjang $\operatorname{lag} \mathrm{p}=6$, maka model VAR (6) yang diaplikasikan dalam studi ini dapat dituliskan dalam bentuk persamaan :

$$
\begin{aligned}
& P P h_{-} N M_{t}=a_{10}+\sum_{j=1}^{6} a_{11} P P h_{N M_{t-j}}+ \\
& \sum_{j=1}^{6} \beta_{11} \text { Growth }_{t-j}+\sum_{j=1}^{6} \gamma_{11} \text { Inflasi }_{t-j}+ \\
& \sum_{j=1}^{6} \delta_{11} \text { Kurs }_{t-j}+\sum_{j=1}^{6} \varepsilon_{11} I C P_{t-j}+v_{1 t} \\
& \text { Growth }_{t}=a_{20}+\sum_{j=1}^{6} a_{21} P P h_{N M_{t-j}}+ \\
& \sum_{j=1}^{6} \beta_{21} \text { Growth }_{t-j}+\sum_{j=1}^{6} \gamma_{21} \text { Inflasi }_{t-j}+ \\
& \sum_{j=1}^{6} \delta_{21} \text { Kurs }_{t-j}+\sum_{j=1}^{6} \varepsilon_{21} I C P_{t-j}+v_{2 t} \\
& \text { Inflasi }_{t}=a_{30}+\sum_{j=1}^{6} a_{31} P P h_{N M_{t-j}}+ \\
& \sum_{j=1}^{6} \beta_{31} \text { Growth }_{t-j}+\sum_{j=1}^{6} \gamma_{31} \text { Inflasi }_{t-j}+ \\
& \sum_{j=1}^{6} \delta_{31} \operatorname{Kurs}_{t-j}+\sum_{j=1}^{6} \varepsilon_{31} I C P_{t-j}+\mathrm{v}_{3 t} \\
& \text { Kurs }_{t}=a_{40}+\sum_{j=1}^{6} a_{41} P P h_{N M_{t-j}}+\sum_{j=1}^{6} \beta_{41} \text { Growth }_{t-j}+ \\
& \sum_{j=1}^{6} \gamma_{41} \text { Inflasi }_{t-j}+\sum_{j=1}^{6} \delta_{41} \text { Kurs }_{t-j}+\sum_{j=1}^{6} \varepsilon_{41} \text { ICP }_{t-j}+ \\
& \mathrm{v}_{4 t} \\
& I C P_{t}=a_{50}+\sum_{j=1}^{6} a_{51} P P h_{N M_{t-j}}+\sum_{j=1}^{6} \beta_{51} \text { Growth }_{t-j}+ \\
& \sum_{j=1}^{6} \gamma_{51} \text { Inflasi }_{t-j}+\sum_{j=1}^{6} \delta_{51} \text { Kurs }_{t-j}+\sum_{j=1}^{6} \varepsilon_{51} I C P_{t-j}+ \\
& \mathrm{v}_{5 t} \ldots \ldots
\end{aligned}
$$

$\mathrm{u} 1 \mathrm{t}, \mathrm{u} 2 \mathrm{t}, \mathrm{u} 3 \mathrm{t}, \mathrm{u} 4 \mathrm{t}$, dan u $5 \mathrm{t}$ merupakan stochastic error terms, yang dalam bahasa VAR disebut impulses atau shocks (goncangan). Stabilitas sistem VAR dilihat dari nilai inverse roots karakteristik AR polinomialnya. Suatu sistem VAR dikatakan stabil (stasioner) jika seluruh roots-nya memiliki modulus lebih kecil dari satu dan semuanya terletak di dalam unit circle (Lutkepohl 1991). Hasil pengujian menunjukkan bahwa sistem VAR (6) stabil (stasioner). Hasil pengujian secara lengkap disajikan pada Lampiran 3.

\subsection{Hasil Estimasi Model VAR}

Studi ini bertujuan memperoleh bukti empiris atas dampak dinamika makro ekonomi terhadap PPh non migas. Untuk itu, hasil estimasi model VAR (6) pada persamaan (1) dibahas secara khusus dan mendalam.
Hasil estimasi model disajikan secara lengkap pada Lampiran 4. Berdasarkan estimasi model, pertumbuhan PPh non migas dapat dijelaskan oleh model VAR sebagai berikut:

PPH_NM $\mathbf{t}_{\mathbf{t}}=-0.023 * \mathrm{PPH} \mathrm{NM}(-1)+0.21 * \mathrm{PPH} \mathrm{NM}(-2)$ $0.59 * \mathrm{PPH}$ NM(-3) $+0.14 * \mathrm{PPH} \mathrm{NM}(-4)-0.09 * \mathrm{PPH} \mathrm{NM}(-5)-$ $0.09 * \mathrm{PPH}_{2} \mathrm{NM}(-6)+3.2 * \mathrm{GROWTH}(-1)+2.0 * \mathrm{GROWTH}(-2)+$ $1.6 *$ GROWTH(-3) - 1.5*GROWTH(-4) - 0.01*GROWTH(-5) $1.95 *$ GROWTH $(-6)+1.65 *$ INFLASI $(-1)-0.67 *$ INFLASI $(-2)+$ $1.55 *$ INFLASI $(-3)+0.90 *$ INFLASI $(-4)-0.96 *$ INFLASI $(-5)$ $0.08 *$ INFLASI $(-6)-0.19 *$ KURS $(-1)+0.40 *$ KURS $(-2)+0.26 *$ KURS $(-3)-$ $0.34 *$ KURS $(-4)+0.14 *$ KURS $(-5)-0.001 *$ KURS $(-6)+0.03 * I C P(-1)-$ $0.15 * I C P(-2)-0.03 * I C P(-3)-0.14 * I C P(-4)+0.07 * I C P(-5)-0.05 * I C P(-6)$ -9.06 .

Secara kolektif, koefisien-koefisien tersebut signifikan dengan basis uji $\mathrm{F}$ standar. Nilai $\mathrm{R}$ squared sebesar 94,5 \%. Sedangkan nilai adjusted $\boldsymbol{R}$ Squared model VAR PPh non migas tersebut diatas sebesar 78,20 \% yang berarti bahwa pertumbuhan PPh non migas dapat dijelaskan oleh variabel-variabel dalam model sebesar 78,2 \% sedangkan sisanya sebesar 21,8\% dijelaskan oleh variabel lain diluar model.

Interpretasi hasil koefisien regresi persamaan diatas tersebut akan dibahas sebagai bagian dari elaborasi analisis dan interpretasi hasil impulse response function (IRF) dan variance decomposition (VDC).

\subsection{Impulse Response Function (IRF)}

Hasil estimasi Impulse Response Function (IRF) membahas respon dari variabel PPh non migas atas shock (guncangan) sebesar satu standar deviasi Cholesky (Cholesky One S.D.) dari variabel pertumbuhan ekonomi, inflasi, kurs, dan harga minyak mentah Indonesia (ICP). Respon PPh non migas terhadap shock (guncangan) dari masing-masing variabel disajikan pada Lampiran 5.

Shock (guncangan) PPh non migas sebesar satu standar deviasi akan menyebabkan pertumbuhan PPh non migas itu sendiri naik menjadi $10 \%$ pada tahun pertama. Namun pertumbuhannya mengalami fluktuatif hingga tahun kelima. Setelah mengalami kenaikan ditahun pertama, berangsur-angsur pertumbuhannya mengalami penurunan hingga tahun ketiga. Pada tahun keempat pertumbuhan PPh non migas mengalami kenaikan kembali lalu menurun di tahun ke lima. Setelah itu shock yang terjadi pada PPh non migas relatif menuju ke titik keseimbangan (convergence). Jika grafik impulse respon menunjukkan pergerakan yang semakin mendekati titik keseimbangan (convergence), berarti respon PPh non migas akibat suatu shock/guncangannya sendiri (inersia) semakin lama akan makin menghilang.

Shock (guncangan) tingkat inflasi sebesar satu standar deviasi pada tahun pertama tidak mempunyai dampak terhadap pertumbuhan PPh non migas. Namun pada tahun kedua hingga ke tujuh, shock tersebut mempunyai pengaruh fluktuatif terhadap pertumbuhan PPh non migas. Shock (guncangan) tingkat inflasi sebesar satu standar deviasi pada tahun kedua akan berdampak meningkatkan pertumbuhan PPh non migas sebesar $6 \%$. Setelah mengalami kenaikan ditahun 
kedua, berangsur-angsur pertumbuhannya mengalami penurunan hingga tahun ketiga. Pada tahun keempat dan kelima shock dari inflasi akan meningkatkan pertumbuhan PPh non migas, lalu menurun kembali di tahun ke enam. Setelah itu pada tahun ke-7 shock yang terjadi pada PPh non migas relatif menuju ke titik keseimbangan (convergence).

Shock (guncangan) nilai tukar sebesar satu standar deviasi pada tahun pertama tidak mempunyai dampak terhadap pertumbuhan PPh non migas. Namun pada tahun kedua, shock (guncangan) yang terjadi pada nilai tukar sebesar satu standar deviasi mempunyai dampak terhadap penurunan PPh non migas sebesar 3 $\%$. Pada tahun-tahun selanjutnya hingga tahun ke-8, shock tersebut mempunyai pengaruh fluktuatif terhadap pertumbuhan PPh non migas. Setelah tahun ke-8, shock yang terjadi pada PPh non migas relatif menuju ke titik keseimbangan (convergence). Respon variabel PPh non migas akibat suatu guncangan (shock) nilai tukar rupiah makin lama akan makin menghilang, sehingga shock perubahan nilai tukar rupiah tersebut tidak meninggalkan pengaruh permanen terhadap variabel PPh non migas.

Shock (guncangan) harga minyak mentah Indonesia (ICP) sebesar satu standar deviasi pada tahun pertama dan kedua tidak mempunyai dampak terhadap pertumbuhan PPh non migas. Namun pada tahun ke-3 hingga ke-7, shock tersebut mempunyai pengaruh negatif terhadap pertumbuhan PPh non migas. Shock (guncangan) harga minyak mentah Indonesia (ICP) sebesar satu standar deviasi pada tahun ke-3 hingga ke7 akan berdampak menurunkan pertumbuhan PPh non migas sebesar 1 s.d $2 \%$. Setelah itu pada tahun ke-8 shock yang terjadi pada PPh non migas relatif menuju ke titik keseimbangan (convergence).

Shock (guncangan) pertumbuhan ekonomi sebesar satu standar deviasi pada tahun pertama tidak mempunyai dampak terhadap pertumbuhan PPh non migas. Namun pada tahun kedua dan ketiga, shock (guncangan) yang terjadi pada pertumbuhan ekonomi sebesar satu standar deviasi mempunyai dampakterhadap peningkatan PPh non migas. Pada tahun ke-3 shock tersebut akan meningkatkan pertumbuhan PPh non migas sebesar $4 \%$. Pada tahuntahun selanjutnya hingga tahun ke-8, shock tersebut mempunyai pengaruh fluktuatif terhadap pertumbuhan PPh non migas. Setelah tahun ke-8, shock yang terjadi pada PPh non migas relatif menuju ke titik keseimbangan (convergence).

\subsection{Hasil Forecasting Error Variance Decomposition (FEVD)}

FEVD menggambarkan perubahan suatu variabel dengan menunjukkan perubahan error variance-nya yang diakibatkan oleh variabel-variabel lain, sehingga dapat diketahui secara pasti faktor-faktor yang memengaruhi fluktuasi dari variabel tertentu (Firdaus, 2011). Hasil estimasi FEVD atas pertumbuhan PPh non migas ditunjukkan pada Lampiran 6.

Hasil FEVD terhadap pertumbuhan PPh non migas menunjukkan bahwa pada tahun pertama, pertumbuhan PPh non migas hanya dipengaruhi oleh guncangan (shock) yang terjadi pada PPh non migas itu sendiri. Pada tahun ke dua, pertumbuhan PPh non migas dipengaruhi oleh dinamika perubahan PPh non migas itu sendiri sebesar $70,98 \%$, tingkat inflasi $20,0 \%$, nilai tukar $8,5 \%$, harga minyak mentah Indonesia $0,3 \%$, dan pertumbuhan ekonomi $0,22 \%$. Namun kemudian pada tahun ke-3, besaran komposisi pengaruh masing-masing variabel tersebut mengalami perubahan signifikan. Pada tahun ke-3, pertumbuhan PPh non migas dipengaruhi oleh dinamika perubahan PPh non migas itu sendiri sebesar 26,1\%, kurs sebesar 60,4\%, tingkat inflasi sebesar $7,2 \%$, pertumbuhan ekonomi $6,1 \%$, dan harga minyak mentah Indonesia sebesar $0,3 \%$. Mulai tahun ketujuh terdapat kencenderungan masing-masing variabel dapat menjelaskan PPh non migas secara lebih stabil (tidak fluktuatif). PPh non migas dipengaruhi oleh kurs $(52,7 \%)$, inflasi $(7,6 \%)$, pertumbuhan ekonomi (6,5\%), dan ICP (2\%). PPh non migas berpengaruh sekitar $31 \%$ terhadap dirinya sendiri.

\subsection{Uji Kausalitas}

Uji kausalitas Granger dilakukan untuk mengetahui hubungan kausalitas di antara variabel-variabel yang ada dalam model. Berdasarkan uji tersebut, pertumbuhan ekonomi dan tingkat inflasi berpengaruh secara langsung dan signifikan terhadap PPh non migas. Perubahan kurs berpengaruh secara signifikan baik terhadap pertumbuhan ekonomi maupun tingkat inflasi. Oleh karena pertumbuhan ekonomi dan tingkat inflasi mempunyai pengaruh signifikan terhadap PPh non migas, maka secara tidak langsung perubahan kurs melalui pertumbuhan ekonomi dan tingkat inflasi memiliki pengaruh yang signifikan terhadap PPh non migas. Berdasarkan uji kausalitas Granger tersebut dibuktikan adanya hubungan satu arah pada model VAR yang digunakan, yaitu pertumbuhan ekonomi, tingkat inflasi, dan kurs mempengaruhi PPh non migas. Hasil uji kausalitas Granger disajikan secara lengkap pada Lampiran 7.

Dampak pertumbuhan ekonomi terhadap Pajak Penghasilan non migas dalam studi ini hasilnya sama dengan penelitian yang dilakukan Rahmanta (2009), Edeme (2016), dan Sitinjak (2016). Sedangkan terkait inflasi, studi ini memperkuat studi yang dilakukan sebelumnya oleh Crane (1986), Saepudin (2008), Arianto (2014). Inflasi mempunyai pengaruh terhadap PPh non migas. Sedangkan terkait dengan nilai tukar rupiah terhadap USD dalam studi ini sama dengan hasil studi Puspitaningrum (2014).

\section{KESIMPULAN}

1. Selama rentang periode kajian 1970 s.d 2017, sejak tahun 1975 PPh non migas memberikan kontribusi utama pada penerimaan perpajakan.

2. Hasil uji kausalitas Granger menunjukkan terdapat hubungan satu arah antara pertumbuhan ekonomi, tingkat inflasi, nilai tukar rupiah dan PPh non migas. Variabel tersebut secara signifikan mempengaruhi PPh non migas, sebaliknya PPh non migas tidak memengaruhi variabel-variabel ekonomi makro tersebut. 
3. Hasil analisis Impuls Respon Function dapat dibuktikan bahwa pertumbuhan PPh non migas rata-rata mencapai kestabilan dalam jangka waktu 8 tahun ketika berhadapan dengan guncangan pada variabel ekonomi makro. Pertumbuhan PPh non migas paling cepat mencapai kestabilan ketika berhadapan dengan guncangan pada tingkat inflasi dibandingkan dengan guncangan pada variabel lainnya.

4. Hasil analisis Forecasting Error Variance Decomposition, dapat disimpulkan bahwa pada tahun pertama dan kedua, pertumbuhan PPh non migas secara dominan dipengaruhi oleh guncangan (shock) yang terjadi pada PPh non migas itu sendiri. Mulai tahun ketujuh terdapat kencenderungan variabel ekonomi makro dapat menjelaskan PPh non migas secara lebih stabil. PPh non migas dipengaruhi oleh kurs $(52,7 \%)$, inflasi $(7,6 \%)$, pertumbuhan ekonomi (6,5\%), dan ICP (2\%).

\section{REKOMENDASI KEBIJAKAN}

Dinamika ekonomi makro mempunyai dampak yang signifikan terhadap pertumbuhan PPh non migas. Dalam rangka menjaga pertumbuhan PPh non migas, maka Pemerintah perlu terus menjaga kondisi ekonomi makro tetap stabil. Serangkaian kebijakan dapat dilakukan baik oleh Pemerintah Pusat maupun Pemerintah daerah. APBN dan APBD dapat diupayakan memberikan multiplier effect yang tinggi guna mendukung pertumbuhan ekonomi. Untuk pengendalian inflasi, Pemerintah dan Pemerintah Daerah perlu berkoordinasi secara aktif dalam menjaga stabilisasi harga di setiap wilayah, meminimalisasi fluktuasi harga melalui penyediaan pasokan dan ketersediaan pangan. Stabilitas nilai tukar rupiah dan stabilitas sistem keuangan perlu terus dijaga. Untuk itu, Pemerintah Pusat perlu terus melakukan koordinasi dengan Pemerintah daerah dan Bank Indonesia selaku otoritas moneter dalam mendesain bauran kebijakan fiskal, moneter, serta sektor riil. Upaya menjaga ekonomi makro secara empiris mempunyai dampak terhadap pertumbuhan PPh non migas.

\section{DAFTAR PUSTAKA}

Arianto, Puspita Suci dan Yazid Yud Padmono. 2014. Faktor-Faktor Yang Mempengaruhi Penerimaan Pajak Daerah di Kota Surabaya. Jurnal Ilmu \& Riset Akuntansi Vol. 3 No. 1.

Berlianta, Heli Chrisma. 2005. Mengenal Valuta Asing. Yogyakarta: Gadjah Mada University Press

BKF (2017). Kajian Pengembangan Model Proyeksi Penerimaan Perpajakan. http://www.fiskal.kemenkeu.go.id/data/doc ument/2017/kajian/Kajian\%20Pengembanga n\%20Model\%20Proyeksi\%20Penerimaan\%20 Perpajakan.pdf

BPS. 2016. Konsep Inflasi. Diakses melalui http://www.bps.go.id/Subjek/view/id/3.
Crane, Steven E. dan Nourzad, Farrokh. 1986. Inflation and Tax Evasion: An Empirical Analysis. The Review of Economics and Statistics Vol. 68, No. 2.

Edeme, R. Kojo. Nkalu, C. Nelson. Azu, Benedict. 2016. Alternative Specification And Estimation of Tax Revenue-Gross Domestic Product Relationship. Asian Journal of Economic Modelling.

Firdaus, Muhammad, 2011. Ekonometrika: Suatu Pendekatan Aplikatif, Edisi Kedua, Cetakan Pertama, Jakarta : Bumi Aksara.

Gujarati, N. D. 2004. Dasar-dasar Ekonometrika Jilid I. Erlangga. Jakarta.

Juanda, Bambang,. Junaidi. 2012. Ekonometrika Deret Waktu : Teori dan Aplikasi. PT Penerbit IPB Press.

Karlina, Nita,. Dudi Pratomo,. Annisa Nurbaiti. 2016. Pengaruh PPnBM dan Nilai Tukar Rupiah Terhadap Penerimaan Pajak (Studi Empiris pada Kantor Pelayanan Pajak (KPP) Madya Bandung tahun 2010-2015). e-Proceeding of Management : Vol.3, No.3 December 2016.

Kurniawan, Teguh. 2007. Pengaruh Pertumbuhan Ekonomi dan Tingkat Inflasi Terhadap Realisasi Penerimaan PPN Barang dan Jasa dan PPnBM di Indonesia. Skripsi. Sekolah Tinggi Akuntansi Negara, Jakarta.

Lisnawati. 2016. Dampak Penurunan Harga Minyak Terhadap Perekonomian Indonesia. Info Ekonomi dan kebijakan Publik. Vol. VIII, No. 02/II/P3DI/Januari/2016

Murni, A. (2006). Ekonomika Makro. Jakarta: PT Refika Aditama.

Musgrave, Richard A., and Peggy B. Musgrave. Public Finance in Theory and Practice. McGraw Hill Book Company, 1989.

Neriswad (2002). Pengaruh Inflasi Terhadap Nilai Riil Penerimaan Pajak Negara: Pendekatan Elastisitas dan Tax Collection Lags di Indonesia. Jurnal Analisa Kebijakan Vol.1 No.1

Pemerintah Republik Indonesia. 2017. Buku II Nota Keuangan beserta Anggaran Pendapatan dan Belanja Negara Tahun 2017.

Prawironegoro, A.W. 2011. Determinan Penerimaan Pajak Daerah di Kota Surabaya. Skripsi. Program Sarjana Sekolah Tinggi Ilmu Ekonomi Indonesia. Surabaya.

Pratama, Nicola Putra. Dwiatmanto. dan Rosalita Rachma Agusti. 2016. Pengaruh inflasi, Pemeriksaan Pajak, dan Jumlah Wajib Pajak Terhadap Penerimaan Pajak Penghasilan (Studi Pada Kantor Pelayanan Pajak Pratama Malang Utara Periode 2010 Sampai 2014). Jurnal Perpajakan (JEJAK) Vol. 8 No. 1. 2016

Puspitaningrum, Rosita, dan Suhandak, Zahroh. 2014. Pengaruh Tingkat Inflasi, Tingkat Suku Bunga SBI, dan Pertumbuhan Ekonomi Terhadap Nilai Tukar Rupiah. Jurnal Administrasi Bisnis Vol 8. No. 1 Februari 2014 
Rahmanta (2009). Pengaruh Produk Domestik Bruto dan SBI Terhadap Penerimaan Pajak di Indonesia. QE Journal, vol. 1 (no. 1)

Renata, Almira Herna., Kadarisman Hidayat., dan Bayu Kaniskha. 2016. Pengaruh Inflasi, Nilai Tukar Rupiah Dan Jumlah Pengusaha Kena Pajak Terhadap Penerimaan Pajak Pertambahan Nilai (Studi pada Kantor Wilayah DJP Jawa Timur I). Jurnal Perpajakan (JEJAK) | Vol. 9 No. 12016.

Richard dan Agus Arianto Toly. 2013. Analisa Korelasi Inflasi, Economic Growth, Economic Structure, dan Tax Rate Terhadap Tax Revenue di Negara-Negara ASEAN. Tax \& Accounting Review, VOL. 3, NO.2.

Saepudin. 2008. Analisis Faktor-Faktor Yang Mempengaruhi Pajak Pertambahan Nilai Di Sumatera Utara. Tesis Sekolah Pasca Sarjana Universitas Sumatera Utara. Medan.
Sukirno, Sadono. 2011. Makroekonomi Teori Pengantar. Edisi ketiga. Jakarta: PT Raja Grafindo Persada.

Sinaga, Andar Rohnal. 2010. Pengaruh Variabel-Variabel Makro Ekonomi Terhadap Penerimaan Pajak di Indonesia. Tesis. Fakultas Ekonomi, Universitas Indonesia.

Sitinjak, Norman Duma. 2016. Dampak Inflasi, Pertumbuhan Jumlah Pekerja, dan Pertumbuhan PDB per kapita Terhadap Penerimaan Pajak. Jurnal EKSIS. Vol XI No 2.

Wahyudi, Eddi. Bunasor Sanim. Hermanto Siregar. Nunung Nuryartono. 2009. Pengaruh Economic Shock Terhadap Penerimaan Pajak Pada Kantor Wilyah Pajak di Indonesia. Jurnal Ekonomi Pembangunan. Vol. 10, No.1, Juni 2009, hal. $68-83$.

\section{DAFTAR LAMPIRAN}

\section{Lampiran 1 : Unit root test}

Group unit root test: Summary

Series: PPH_NM, GROWTH, INFLASI, KURS, ICP

Date: $11 / 18 / 17$ Time: 08:26

Sample: 19702016

Exogenous variables: Individual effects

Automatic selection of maximum lags

Automatic lag length selection based on SIC: 0

Newey-West automatic bandwidth selection and Bartlett kernel

Balanced observations for each test

\begin{tabular}{|c|c|c|c|c|}
\hline Method & Statistic & Prob.** & $\begin{array}{c}\text { Cross- } \\
\text { sections }\end{array}$ & Obs \\
\hline \multicolumn{5}{|c|}{ Null: Unit root (assumes common unit root process) } \\
\hline Levin, Lin \& Chu t* & -14.5052 & 0.0000 & 5 & 230 \\
\hline \multicolumn{5}{|c|}{ Null: Unit root (assumes individual unit root process) } \\
\hline Im, Pesaran and Shin W-stat & -13.3836 & 0.0000 & 5 & 230 \\
\hline ADF - Fisher Chi-square & 136.893 & 0.0000 & 5 & 230 \\
\hline PP - Fisher Chi-square & 134.818 & 0.0000 & 5 & 230 \\
\hline
\end{tabular}

** Probabilities for Fisher tests are computed using an asymptotic Chi -square distribution. All other tests assume asymptotic normality.

\section{Lampiran 2 : Penentuan Kandidat Lag}

VAR Lag Order Selection Criteria

Endogenous variables: PPH_NM GROWTH INFLASI KURS ICP

Exogenous variables: $\mathrm{C}$

Date: 11/18/17 Time: 08:51

Sample: 19702016

Included observations: 41

\begin{tabular}{ccccccc}
\hline \hline Lag & LogL & LR & FPE & AIC & SC & HQ \\
\hline \hline 0 & -808.5647 & NA & $1.18 \mathrm{e}+11$ & 39.68608 & 39.89506 & 39.76218 \\
1 & -750.0395 & $99.92110^{*}$ & $2.33 \mathrm{e}+10$ & 38.05071 & $39.30454^{*}$ & 38.50728 \\
2 & -727.3438 & 33.21318 & $2.76 \mathrm{e}+10$ & 38.16311 & 40.46181 & 39.00017 \\
3 & -700.6944 & 32.49928 & $2.96 \mathrm{e}+10$ & 38.08265 & 41.42621 & 39.30019 \\
4 & -670.3297 & 29.62414 & $3.13 \mathrm{e}+10$ & 37.82096 & 42.20938 & 39.41898 \\
5 & -635.9567 & 25.15095 & $3.63 \mathrm{e}+10$ & 37.36374 & 42.79702 & 39.34224
\end{tabular}




\begin{tabular}{llllll}
\hline 6 & -566.0539 & 34.09894 & $1.31 e+10^{*}$ & $35.17336^{*}$ & 41.65150 \\
\hline \hline
\end{tabular}

* indicates lag order selected by the criterion

LR: sequential modified LR test statistic (each test at $5 \%$ level)

FPE: Final prediction error

AIC: Akaike information criterion

SC: Schwarz information criterion

HQ: Hannan-Quinn information criterion

Lampiran 3 : Pengujian Kestabilan Sistem VAR (6)

Roots of Characteristic Polynomial

Endogenous variables: PPH_NM GROWTH INFLASI KURS ICP

Exogenous variables: $\mathrm{C}$

Lag specification: 16

Date: 11/18/17 Time: 09:45

\begin{tabular}{|c|c|}
\hline Root & Modulus \\
\hline $0.043605+0.949406 i$ & 0.950407 \\
\hline $0.043605-0.949406 i$ & 0.950407 \\
\hline $0.381461+0.865474 i$ & 0.945811 \\
\hline $0.381461-0.865474 i$ & 0.945811 \\
\hline $0.882018+0.293951 i$ & 0.929711 \\
\hline $0.882018-0.293951 \mathrm{i}$ & 0.929711 \\
\hline $0.650538-0.644183 i$ & 0.915517 \\
\hline $0.650538+0.644183 i$ & 0.915517 \\
\hline$-0.496833-0.746782 i$ & 0.896954 \\
\hline$-0.496833+0.746782 i$ & 0.896954 \\
\hline$-0.257982-0.848224 i$ & 0.886588 \\
\hline$-0.257982+0.848224 i$ & 0.886588 \\
\hline$-0.783584-0.414391 i$ & 0.886410 \\
\hline$-0.783584+0.414391 i$ & 0.886410 \\
\hline$-0.844424-0.254603 i$ & 0.881972 \\
\hline$-0.844424+0.254603 i$ & 0.881972 \\
\hline $0.866229+0.151743 i$ & 0.879419 \\
\hline $0.866229-0.151743 \mathrm{i}$ & 0.879419 \\
\hline$-0.637783+0.574277 i$ & 0.858232 \\
\hline$-0.637783-0.574277 i$ & 0.858232 \\
\hline $0.458752-0.713763 i$ & 0.848476 \\
\hline $0.458752+0.713763 i$ & 0.848476 \\
\hline $0.646333-0.521836 i$ & 0.830698 \\
\hline $0.646333+0.521836 i$ & 0.830698 \\
\hline-0.823470 & 0.823470 \\
\hline$-0.055281+0.748413 i$ & 0.750452 \\
\hline$-0.055281-0.748413 i$ & 0.750452 \\
\hline-0.739411 & 0.739411 \\
\hline$-0.161762+0.537089 i$ & 0.560920 \\
\hline$-0.161762-0.537089 i$ & 0.560920 \\
\hline
\end{tabular}

No root lies outside the unit circle.

VAR satisfies the stability condition.

\section{Lampiran 4 : Hasil Estimasi Model VAR}

Vector Autoregression Estimates

Date: 11/18/17 Time: 09:31

Sample (adjusted): 19762016

Included observations: 41 after adjustments

Standard errors in ( ) \& t-statistics in [ ]

\begin{tabular}{cccccc}
\hline \hline & PPH_NM & GROWTH & INFLASI & KURS & ICP \\
\hline \hline PPH_NM(-1) & -0.022813 & 0.023960 & -0.123506 & 0.123356 & 0.894601
\end{tabular}




\begin{tabular}{|c|c|c|c|c|c|}
\hline & (0.31154) & $(0.08448)$ & $(0.18602)$ & (0.78109) & (1.04902) \\
\hline & {$[-0.07323]$} & [ 0.28361$]$ & {$[-0.66394]$} & [ 0.15793] & [0.85280] \\
\hline \multirow[t]{3}{*}{ PPH_NM(-2) } & 0.206830 & -0.014775 & 0.360291 & -0.514422 & 1.475913 \\
\hline & $(0.26196)$ & (0.07104) & $(0.15642)$ & $(0.65680)$ & (0.88209) \\
\hline & [ 0.78953] & {$[-0.20799]$} & [ 2.30336] & {$[-0.78323]$} & [ 1.67320$]$ \\
\hline \multirow[t]{3}{*}{ PPH_NM(-3) } & -0.586013 & 0.044183 & -0.184940 & -0.069789 & -0.909335 \\
\hline & $(0.25656)$ & $(0.06957)$ & (0.15319) & (0.64325) & $(0.86390)$ \\
\hline & {$[-2.28411]$} & [ 0.63505] & {$[-1.20723]$} & {$[-0.10849]$} & {$[-1.05260]$} \\
\hline \multirow[t]{3}{*}{ PPH_NM(-4) } & 0.138936 & 0.001932 & -0.012183 & 0.256868 & 0.078161 \\
\hline & (0.15879) & $(0.04306)$ & $(0.09482)$ & $(0.39813)$ & $(0.53470)$ \\
\hline & [ 0.87494] & [ 0.04488] & {$[-0.12849]$} & [ 0.64519] & [ 0.14618$]$ \\
\hline \multirow[t]{3}{*}{ PPH_NM(-5) } & -0.088448 & -0.005519 & 0.140028 & -0.304221 & 0.014451 \\
\hline & (0.15321) & $(0.04155)$ & (0.09148) & $(0.38412)$ & (0.51588) \\
\hline & {$[-0.57732]$} & {$[-0.13284]$} & [ 1.53069] & {$[-0.79200]$} & [ 0.02801] \\
\hline \multirow[t]{3}{*}{ PPH_NM(-6) } & -0.092382 & 0.016888 & 0.010001 & -0.119024 & 0.088841 \\
\hline & (0.12672) & (0.03436) & $(0.07567)$ & $(0.31772)$ & $(0.42670)$ \\
\hline & {$[-0.72901]$} & [ 0.49144$]$ & [ 0.13217$]$ & {$[-0.37462]$} & [0.20820] \\
\hline \multirow[t]{3}{*}{ GROWTH(-1) } & 3.216447 & 0.485897 & -0.356529 & -6.387086 & 2.236555 \\
\hline & $(1.98563)$ & $(0.53845)$ & (1.18563) & (4.97837) & (6.68605) \\
\hline & [ 1.61986] & [ 0.90240] & {$[-0.30071]$} & {$[-1.28297]$} & [ 0.33451$]$ \\
\hline \multirow[t]{3}{*}{ GROWTH(-2) } & 2.030877 & -0.617154 & 1.584571 & 4.555674 & -11.12516 \\
\hline & $(1.82677)$ & $(0.49537)$ & $(1.09078)$ & (4.58009) & (6.15115) \\
\hline & [ 1.11173] & {$[-1.24583]$} & [ 1.45270$]$ & [ 0.99467] & {$[-1.80863]$} \\
\hline \multirow[t]{3}{*}{ GROWTH(-3) } & 1.620658 & 0.374310 & 0.798399 & 0.474601 & 0.911365 \\
\hline & (2.10149) & $(0.56987)$ & $(1.25481)$ & $(5.26885)$ & (7.07617) \\
\hline & [ 0.77120] & [ 0.65683] & [ 0.63627] & [ 0.09008] & [ 0.12879] \\
\hline \multirow[t]{3}{*}{ GROWTH(-4) } & -1.479097 & -0.226631 & -0.052167 & 3.862247 & -9.152830 \\
\hline & (1.71404) & $(0.46480)$ & $(1.02346)$ & $(4.29745)$ & (5.77156) \\
\hline & {$[-0.86293]$} & {$[-0.48758]$} & {$[-0.05097]$} & [ 0.89873] & {$[-1.58585]$} \\
\hline \multirow[t]{3}{*}{ GROWTH(-5) } & -0.005430 & -0.112176 & 0.196705 & 0.739209 & 4.420604 \\
\hline & (1.67659) & $(0.45465)$ & $(1.00110)$ & $(4.20356)$ & (5.64546) \\
\hline & [-0.00324] & {$[-0.24673]$} & [ 0.19649$]$ & [ 0.17585$]$ & [ 0.78304$]$ \\
\hline \multirow[t]{3}{*}{ GROWTH(-6) } & -1.947357 & 0.380052 & -2.308663 & 1.329565 & 1.599430 \\
\hline & (1.61482) & $(0.43790)$ & $(0.96422)$ & (4.04868) & (5.43745) \\
\hline & [-1.20593] & [ 0.86790] & {$[-2.39434]$} & [ 0.32839] & [0.29415] \\
\hline \multirow[t]{3}{*}{ INFLASI(-1) } & 1.651446 & 0.205318 & -0.683131 & -2.569706 & 4.168720 \\
\hline & $(0.59273)$ & $(0.16073)$ & $(0.35392)$ & $(1.48610)$ & (1.99586) \\
\hline & [ 2.78616] & [ 1.27738] & [-1.93016] & {$[-1.72916]$} & [ 2.08868] \\
\hline \multirow[t]{3}{*}{ INFLASI(-2) } & -0.669880 & -0.153204 & 0.242400 & 0.216506 & 0.053148 \\
\hline & $(0.57685)$ & (0.15643) & $(0.34444)$ & (1.44629) & (1.94240) \\
\hline & {$[-1.16126]$} & {$[-0.97939]$} & [ 0.70374$]$ & [ 0.14970] & [ 0.02736$]$ \\
\hline \multirow[t]{3}{*}{ INFLASI(-3) } & 1.551136 & 0.155759 & -0.314808 & 0.987490 & 0.606057 \\
\hline & $(0.53176)$ & $(0.14420)$ & $(0.31752)$ & (1.33323) & (1.79055) \\
\hline & [ 2.91700] & [ 1.08017] & {$[-0.99147]$} & [ 0.74068$]$ & [ 0.33848$]$ \\
\hline \multirow[t]{3}{*}{ INFLASI(-4) } & 0.900339 & -0.062700 & 0.977068 & 0.655856 & -0.759434 \\
\hline & $(0.65266)$ & (0.17698) & $(0.38970)$ & $(1.63634)$ & (2.19764) \\
\hline & [ 1.37950$]$ & {$[-0.35427]$} & [ 2.50720] & [ 0.40081] & {$[-0.34557]$} \\
\hline \multirow[t]{3}{*}{ INFLASI(-5) } & -0.960583 & 0.040046 & -0.269349 & 0.649145 & -0.462522 \\
\hline & $(0.59465)$ & $(0.16126)$ & $(0.35507)$ & (1.49092) & (2.00233) \\
\hline & {$[-1.61536]$} & [ 0.24834$]$ & {$[-0.75858]$} & [ 0.43540$]$ & {$[-0.23099]$} \\
\hline
\end{tabular}




\begin{tabular}{|c|c|c|c|c|c|}
\hline INFLASI(-6) & $\begin{array}{r}-0.084257 \\
(0.53062) \\
{[-0.15879]}\end{array}$ & $\begin{array}{r}0.018943 \\
(0.14389) \\
{[0.13165]}\end{array}$ & $\begin{array}{r}-0.322454 \\
(0.31684) \\
{[-1.01773]}\end{array}$ & $\begin{array}{r}1.310680 \\
(1.33038) \\
{[0.98519]}\end{array}$ & $\begin{array}{r}2.917521 \\
(1.78672 \\
{[1.63289}\end{array}$ \\
\hline KURS(-1) & $\begin{array}{r}-0.193858 \\
(0.12691) \\
{[-1.52756]}\end{array}$ & $\begin{array}{r}-0.171799 \\
(0.03441) \\
{[-4.99212]}\end{array}$ & $\begin{array}{c}0.665724 \\
(0.07578) \\
{[8.78530]}\end{array}$ & $\begin{array}{c}0.387492 \\
(0.31818) \\
{[1.21783]}\end{array}$ & $\begin{array}{r}-0.258579 \\
(0.42733) \\
{[-0.60511}\end{array}$ \\
\hline KURS(-2) & $\begin{array}{r}0.399393 \\
(0.26357) \\
{[1.51531]}\end{array}$ & $\begin{array}{r}-0.004477 \\
(0.07147) \\
{[-0.06263]}\end{array}$ & $\begin{array}{r}-0.007881 \\
(0.15738) \\
{[-0.05008]}\end{array}$ & $\begin{array}{c}0.154320 \\
(0.66083) \\
{[0.23352]}\end{array}$ & $\begin{array}{r}-1.300464 \\
(0.88751) \\
{[-1.46530}\end{array}$ \\
\hline KURS(-3) & $\begin{array}{r}0.262903 \\
(0.25507) \\
{[1.03070]}\end{array}$ & $\begin{array}{r}-0.016418 \\
(0.06917) \\
{[-0.23736]}\end{array}$ & $\begin{array}{r}0.285667 \\
(0.15231) \\
{[1.87562]}\end{array}$ & $\begin{array}{r}-0.267779 \\
(0.63952) \\
{[-0.41872]}\end{array}$ & $\begin{array}{r}-1.065510 \\
(0.85889) \\
{[-1.24057}\end{array}$ \\
\hline KURS(-4) & $\begin{array}{r}-0.336473 \\
(0.22502) \\
{[-1.49529]}\end{array}$ & $\begin{array}{r}-0.043960 \\
(0.06102) \\
{[-0.72042]}\end{array}$ & $\begin{array}{r}-0.109869 \\
(0.13436) \\
{[-0.81771]}\end{array}$ & $\begin{array}{r}-0.011791 \\
(0.56418) \\
{[-0.02090]}\end{array}$ & $\begin{array}{r}-1.237713 \\
(0.75770 \\
{[-1.63352}\end{array}$ \\
\hline KURS(-5) & $\begin{array}{c}0.143754 \\
(0.22348) \\
{[0.64325]}\end{array}$ & $\begin{array}{c}0.025024 \\
(0.06060) \\
{[0.41292]}\end{array}$ & $\begin{array}{r}-0.154618 \\
(0.13344) \\
{[-1.15870]}\end{array}$ & $\begin{array}{r}-0.109950 \\
(0.56031) \\
{[-0.19623]}\end{array}$ & $\begin{array}{r}0.610337 \\
(0.75251) \\
{[0.81107]}\end{array}$ \\
\hline KURS(-6) & $\begin{array}{r}-0.001409 \\
(0.17480) \\
{[-0.00806]}\end{array}$ & $\begin{array}{r}-0.035108 \\
(0.04740) \\
{[-0.74065]}\end{array}$ & $\begin{array}{r}0.053316 \\
(0.10438) \\
{[0.51082]}\end{array}$ & $\begin{array}{r}-0.136771 \\
(0.43826) \\
{[-0.31207]}\end{array}$ & $\begin{array}{r}-0.835887 \\
(0.58860 \\
{[-1.42014}\end{array}$ \\
\hline $\mathrm{ICP}(-1)$ & $\begin{array}{r}0.028391 \\
(0.08081) \\
{[0.35135]}\end{array}$ & $\begin{array}{r}-0.017907 \\
(0.02191) \\
{[-0.81718]}\end{array}$ & $\begin{array}{r}0.141596 \\
(0.04825) \\
{[2.93466]}\end{array}$ & $\begin{array}{c}0.259986 \\
(0.20260) \\
{[1.28327]}\end{array}$ & $\begin{array}{r}-0.347752 \\
(0.27209) \\
{[-1.27807}\end{array}$ \\
\hline $\mathrm{ICP}(-2)$ & $\begin{array}{r}-0.151074 \\
(0.10267) \\
{[-1.47140]}\end{array}$ & $\begin{array}{r}-0.005243 \\
(0.02784) \\
{[-0.18829]}\end{array}$ & $\begin{array}{r}-0.045080 \\
(0.06131) \\
{[-0.73532]}\end{array}$ & $\begin{array}{c}0.062313 \\
(0.25742) \\
{[0.24206]}\end{array}$ & $\begin{array}{r}-0.377244 \\
(0.34572 \\
{[-1.09117}\end{array}$ \\
\hline $\operatorname{ICP}(-3)$ & $\begin{array}{r}-0.028992 \\
(0.07937) \\
{[-0.36528]}\end{array}$ & $\begin{array}{r}-0.025063 \\
(0.02152) \\
{[-1.16448]}\end{array}$ & $\begin{array}{c}0.029724 \\
(0.04739) \\
{[0.62722]}\end{array}$ & $\begin{array}{r}-0.186515 \\
(0.19899) \\
{[-0.93730]}\end{array}$ & $\begin{array}{r}-0.129126 \\
(0.26725) \\
{[-0.48317}\end{array}$ \\
\hline ICP $(-4)$ & $\begin{array}{r}-0.135424 \\
(0.08693) \\
{[-1.55790]}\end{array}$ & $\begin{array}{r}-0.033017 \\
(0.02357) \\
{[-1.40066]}\end{array}$ & $\begin{array}{r}0.019390 \\
(0.05190) \\
{[0.37356]}\end{array}$ & $\begin{array}{r}-0.123586 \\
(0.21794) \\
{[-0.56705]}\end{array}$ & $\begin{array}{r}-0.374907 \\
(0.29270 \\
{[-1.28084}\end{array}$ \\
\hline $\mathrm{ICP}(-5)$ & $\begin{array}{r}0.073519 \\
(0.08833) \\
{[0.83235]}\end{array}$ & $\begin{array}{c}0.040244 \\
(0.02395) \\
{[1.68015]}\end{array}$ & $\begin{array}{r}-0.144113 \\
(0.05274) \\
{[-2.73245]}\end{array}$ & $\begin{array}{r}-0.330525 \\
(0.22146) \\
{[-1.49250]}\end{array}$ & $\begin{array}{r}0.198008 \\
(0.29742) \\
{[0.66575}\end{array}$ \\
\hline $\operatorname{ICP}(-6)$ & $\begin{array}{r}-0.048720 \\
(0.08251) \\
{[-0.59046]}\end{array}$ & $\begin{array}{r}-0.016489 \\
(0.02238) \\
{[-0.73692]}\end{array}$ & $\begin{array}{r}0.081762 \\
(0.04927) \\
{[1.65950]}\end{array}$ & $\begin{array}{r}-0.329998 \\
(0.20688) \\
{[-1.59514]}\end{array}$ & $\begin{array}{r}0.038065 \\
(0.27784) \\
{[0.13700}\end{array}$ \\
\hline C & $\begin{array}{r}-9.063726 \\
(12.2192) \\
{[-0.74176]}\end{array}$ & $\begin{array}{r}3.270736 \\
(3.31354) \\
{[0.98708]}\end{array}$ & $\begin{array}{r}1.617847 \\
(7.29616) \\
{[0.22174]}\end{array}$ & $\begin{array}{r}-7.343752 \\
(30.6361) \\
{[-0.23971]}\end{array}$ & $\begin{array}{l}12.81416 \\
(41.1448 \\
{[0.31144}\end{array}$ \\
\hline R-squared & 0.945497 & 0.852867 & 0.936293 & 0.688676 & 0.791539 \\
\hline Adj. R-squared & 0.781989 & 0.411466 & 0.745171 & -0.245295 & 0.166154 \\
\hline $\begin{array}{l}\text { Sum sq. resids } \\
\text { S.E. equation }\end{array}$ & $\begin{array}{l}949.4187 \\
9.743812\end{array}$ & $\begin{array}{l}69.81634 \\
2.642278\end{array}$ & $\begin{array}{l}338.5007 \\
5.818082\end{array}$ & $\begin{array}{l}5968.119 \\
24.42973\end{array}$ & $\begin{array}{l}10764.70 \\
32.80960\end{array}$ \\
\hline F-statistic & 5.782561 & 1.932184 & 4.898932 & 0.737364 & 1.265683 \\
\hline Log likelihood & -122.5932 & -69.08855 & -101.4510 & -160.2791 & -172.3708 \\
\hline Akaike AIC & 7.492350 & 4.882368 & 6.461026 & 9.330687 & 9.920527 \\
\hline Schwarz SC & 8.787978 & 6.177996 & 7.756654 & 10.62631 & 11.21615 \\
\hline Mean dependent & 22.65275 & 5.381951 & 10.13976 & 10.83206 & 8.250140 \\
\hline S.D. dependent & 20.86842 & 3.444236 & 11.52538 & 21.89186 & 35.93006 \\
\hline
\end{tabular}


Determinant resid covariance (dof adj.)

Determinant resid covariance

Log likelihood

Akaike information criterion

Schwarz criterion
$7.82 \mathrm{E}+08$

675358.7

$-566.0539$

35.17336

41.65150

\section{Lampiran 5 : Impuls response Function}

Response to Cholesky One S.D. Innovations \pm 2 S.E.

Response of PPH_NM to PPH_NM

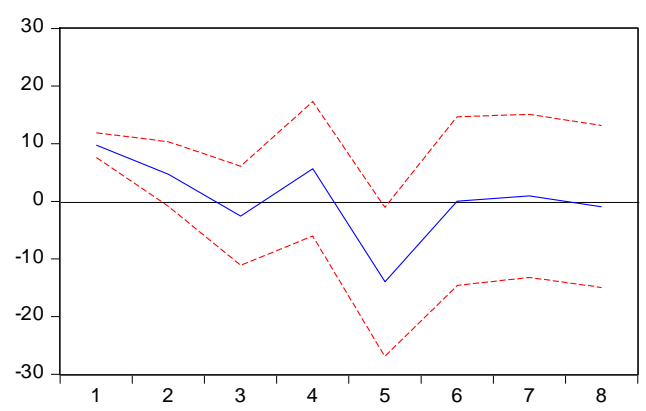

Response of PPH NM to INFLASI

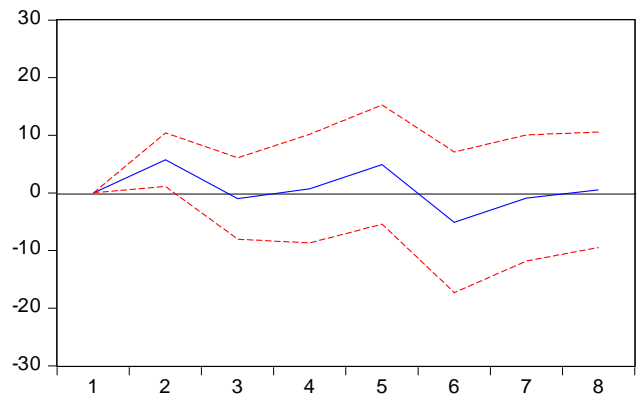

Response of PPH_NM to ICP

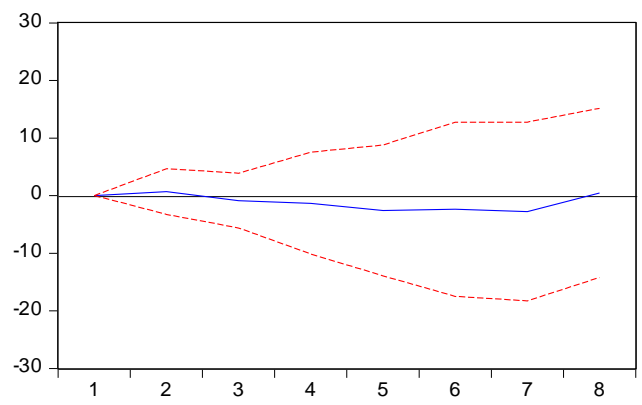

Response of PPH_NM to GROWTH

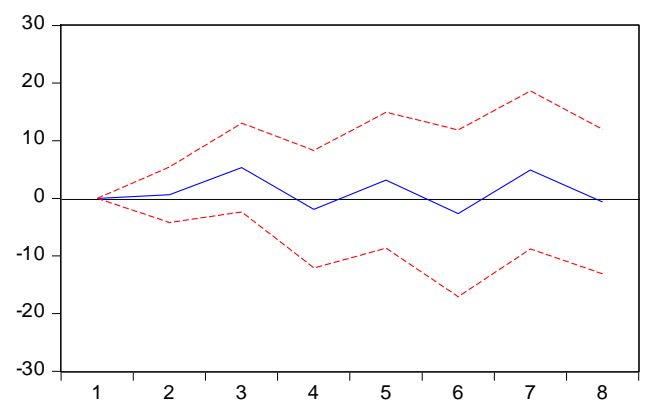

Response of PPH_NM to KURS

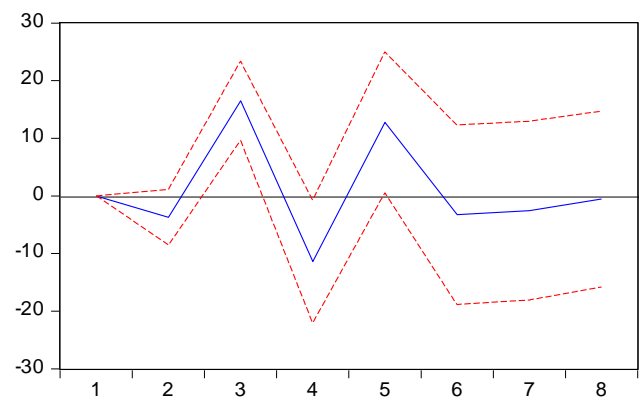

Lampiran 6 : Variance decomposition of PPh Non Migas

\begin{tabular}{ccccccc}
\hline \hline Period & S.E. & PPH_NM & GROWTH & INFLASI & KURS & ICP \\
\hline \hline 1 & 9.743812 & 100.0000 & 0.000000 & 0.000000 & 0.000000 & 0.000000 \\
2 & 12.83922 & 70.97629 & 0.219343 & 20.04899 & 8.462620 & 0.292759 \\
3 & 21.76011 & 26.09022 & 6.062327 & 7.192699 & 60.39121 & 0.263546 \\
4 & 25.31849 & 24.26006 & 5.047922 & 5.397982 & 64.82600 & 0.468032 \\
5 & 32.24937 & 33.72553 & 4.059095 & 5.660312 & 55.62199 & 0.933067 \\
6 & 33.00619 & 32.19674 & 4.517434 & 7.800364 & 54.08004 & 1.405420 \\
7 & 33.60780 & 31.13078 & 6.483750 & 7.592291 & 52.75055 & 2.042633 \\
8 & 33.63804 & 31.15077 & 6.506045 & 7.602963 & 52.68223 & 2.057992 \\
\hline
\end{tabular}




\section{Lampiran 7 : Uji Kausalitas}

Pairwise Granger Causality Tests

Date: 11/18/17 Time: 12:57

Sample: 19702016

Lags: 6

\begin{tabular}{|c|c|c|c|}
\hline Null Hypothesis: & Obs & F-Statistic & Prob. \\
\hline GROWTH does not Granger Cause PPH_NM & 41 & 3.77328 & 0.0071 \\
\hline PPH_NM does not Granger Cause GROWTH & & 0.31073 & 0.9260 \\
\hline INFLASI does not Granger Cause PPH_NM & 41 & 8.41761 & 3.E-05 \\
\hline PPH_NM does not Granger Cause INFLASI & & 0.35616 & 0.9002 \\
\hline KURS does not Granger Cause PPH_NM & 41 & 1.45478 & 0.2297 \\
\hline PPH_NM does not Granger Cause KURS & & 0.12117 & 0.9929 \\
\hline ICP does not Granger Cause PPH_NM & 41 & 0.80685 & 0.5732 \\
\hline PPH_NM does not Granger Cause ICP & & 0.56147 & 0.7571 \\
\hline INFLASI does not Granger Cause GROWTH & 41 & 0.23577 & 0.9611 \\
\hline GROWTH does not Granger Cause INFLASI & & 0.42180 & 0.8582 \\
\hline KURS does not Granger Cause GROWTH & 41 & 3.46525 & 0.0109 \\
\hline GROWTH does not Granger Cause KURS & & 0.26323 & 0.9494 \\
\hline ICP does not Granger Cause GROWTH & 41 & 0.63728 & 0.6994 \\
\hline GROWTH does not Granger Cause ICP & & 1.94201 & 0.1087 \\
\hline KURS does not Granger Cause INFLASI & 41 & 7.77399 & $6 . \mathrm{E}-05$ \\
\hline INFLASI does not Granger Cause KURS & & 0.85719 & 0.5378 \\
\hline ICP does not Granger Cause INFLASI & 41 & 0.12199 & 0.9928 \\
\hline INFLASI does not Granger Cause ICP & & 2.86121 & 0.0266 \\
\hline ICP does not Granger Cause KURS & 41 & 1.04782 & 0.4164 \\
\hline KURS does not Granger Cause ICP & & 0.85328 & 0.5405 \\
\hline
\end{tabular}

